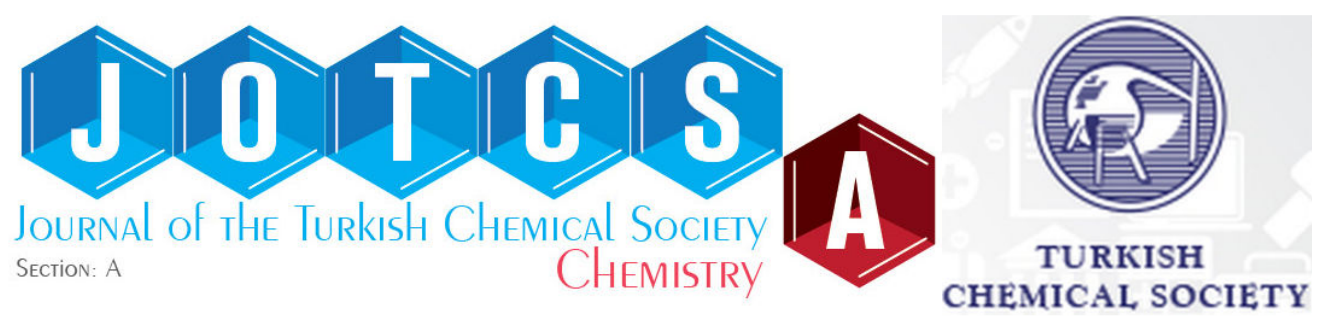

\title{
Comparative Studies on the Phytochemicals, Nutrients and Antinutrients Content of Cassava Varieties
}

\author{
Omolara Olusola Oluwaniyi* and John Olubunmi Oladipo
}

Department of Industrial Chemistry, University of Ilorin, P.M.B 1515, Ilorin, Nigeria

\begin{abstract}
The aim of this research was to investigate and compare the nutritional, antinutritional, and phytochemical composition of two varieties (TME 9 (olekan-aga) and TME 7 (oko-iyawo)) of Manihot esculenta (cassava) tubers at different ages ( 6 months and 12 months). The result of proximate analyses showed that 12 -month-old samples of both varieties had higher moisture contents $(44.3 \pm 0.24,44.7 \pm 0.47)$ compared to the 6-monthold samples $(34.8 \pm 0.62,37.5 \pm 0.71)$. A 12-month-old sample of TME 7 had the lowest ash and protein contents of $1.33 \pm 0.24$ and $2.28 \pm 0.21$ respectively with highest carbohydrate contents of $90.38 \pm 0.7$ among the four samples analyzed. The result of mineral analysis revealed that the predominant mineral is $\mathrm{Ca}(1,209.5,1,273.3,1,276.8$ and $1,178.5 \mathrm{mg} / \mathrm{kg})$ for the 6-month-old TME 9, 12-month-old TME 9, 6-month-old TME 7 and 12-month-old TME 7 respectively), followed by $\mathrm{Na}, \mathrm{Fe}$ and $\mathrm{Mg}$ in that order. Quantitative phytochemical analysis showed that the 12-month-old samples have the largest quantity of alkaloids and saponins $(16.03 \pm 1.70,21.44 \pm 0.56 \mathrm{mg} / 100 \mathrm{~g}$ and $4.41 \pm 0.31,3.54 \pm 0.25 \mathrm{mg} / 100 \mathrm{~g}$ respectively) for both varieties compared with $11.69 \pm 0.43,12.49 \pm 0.53 \mathrm{mg} / 100 \mathrm{~g}$ and $2.39 \pm 0.23,1.84 \pm 0.12$ $\mathrm{mg} / 100 \mathrm{~g}$ recorded for the 6 -month-old samples of both varieties. Flavonoids and tannin contents are lower in the 12 -month-old samples $(2.1 \pm 0.64,2.07 \pm 0.34 \mathrm{mg} / 100 \mathrm{~g}$ and $0.14 \pm 0.03$ and $0.13 \pm 0.04 \mathrm{mg} / 100 \mathrm{~g}$ ) compared with the 6-month-old samples with $3.5 \pm 0.57,3.73 \pm 0.19 \mathrm{mg} / 100 \mathrm{~g}$ and $0.22 \pm 0.05,0.21 \pm 0.02 \mathrm{mg} / 100 \mathrm{~g}$, respectively. Antinutrient contents - oxalates, cyanogenic glycosides and phytates are high for both species at 12 months while the 6-month-old samples recorded the lowest content. The results suggest that the 6-month-old samples are more desirable regarding higher nutrient contents (especially carbohydrate and energy) as well as lower antinutrient contents.
\end{abstract}

Keywords: Phytochemicals, nutrients, antinutrients, cassava varieties.

Submitted: April 15, 2017. Accepted: June 09, 2017.

Cite this: Oluwaniyi $O O$ and Oladipo JO. Comparative Studies on the Phytochemicals, Nutrients and Antinutrients Content of Cassava Varieties. 2017 JOTCSA; 4(3); 661-674.

DOI: $10.18596 /$ jotcsa.306496

*Corresponding author. E-mail: oluwaniyi@unilorin.edu.ng or laraoluwaniyi@yahoo.com; Tel: $+234-8033947875$ 


\section{INTRODUCTION}

Cassava, Manihot esculenta Crantz, is a perennial woody shrub with an edible root. It grows in tropical and subtropical regions and is known by different names in different parts of the world. It is also called yuca, manioc, and mandioca. Cassava is a highly drought-tolerant crop with the ability to grow on marginal lands where cereals and other crops do not grow well; it can tolerate drought and can grow in soils where the nutrient levels are low. Because cassava roots can be stored on the ground for a long time (from 24 to 36 months in some varieties), the harvest is usually delayed until market, processing, or other conditions are favorable. Cassava is the third largest source of food carbohydrates in the tropics, after rice and maize (1). It is a major staple food in the developing world, where it is processed into different types of product for consumption. One of the products made from cassava is tapioca, which is the powdery pearly extract. Another product is garri, which is produced by fermenting and then frying cassava paste into flakes (1). Although Nigeria is the world's largest producer of cassava, Thailand exports more cassava and is the largest exporter of dried cassava. Several varieties of cassava are available and much more are being developed. Cassava varieties are classified according to morphological trails as well as taste, cyanide content, average yield, performance and pubescence (2). More than 5,000 varieties have recognized the world over (3). One way of classifying cassava is as sweet or bitter and the bitter varieties are often preferred by farmers because they deter pests, animals, and thieves (4). Like any other roots and tubers, all varieties of cassava contain antinutritional factors and toxins, though in varying quantities, and must therefore undergo adequate processing and preparation before consumption. Poor processing and preparation can leave sufficient amount of residual cyanide to cause acute cyanide intoxication and goiters, and may even cause ataxia or partial paralysis (4). The aim of this research was to investigate the nutritional, antinutritional, and phytochemical composition of two varieties TME 9 (olekan-aga) and TME 7 (oko-iyawo) of Manihot esculenta (cassava) tubers at different ages ( 6 months and 12 months) of maturation.

\section{EXPERIMENTAL PROCEDURE}

Sample site: Two varieties (TME 9 and TME 7) of Manihot esculenta tubers were used in this study. The tubers were harvested at different ages ( 6 months and 12 months after planting). Samples were collected from a farm settlement in Agric Area, Ogbomoso, Oyo state in Western Nigeria. 
Sample preparation: The samples were washed with clean water, peeled, pulverized, and dried at $80^{\circ} \mathrm{C}$ for 10 hours in an oven. The dried samples were then ground to fine powder using a mortar and pestle.

Analysis of samples: Proximate composition was determined using standard methods of the Association of Official Analytical Chemists (5). Parameters evaluated are: moisture content, ash, crude fat, crude fiber, and protein content. Drying method was used to determine the moisture content. $2.0 \mathrm{~g}$ of each sample was heated to a constant weight in a crucible placed in an oven maintained at $105^{\circ} \mathrm{C} .2 .0 \mathrm{~g}$ of the sample was incinerated in a muffle furnace maintained at $550^{\circ} \mathrm{C}$ for $5 \mathrm{~h}$ to determine the ash content; fat content was obtained by exhaustively extracting $2.0 \mathrm{~g}$ of the sample in a soxhlet apparatus using $\mathrm{n}$-hexane as the extractant. Crude fiber was obtained by digesting $2.0 \mathrm{~g}$ of sample with $\mathrm{H}_{2} \mathrm{SO}_{4}$ and $\mathrm{NaOH}$ and incinerating the residue in a muffle furnace maintained at $550^{\circ} \mathrm{C}$ for $5 \mathrm{~h}$. Crude protein (\% total nitrogen $\times 6.25$ ) was determined by the Kjeldahl method (6) using $2.0 \mathrm{~g}$ of sample. Total carbohydrate was determined by difference. Total energy was estimated according to the method of Osborne and Voogt (7).

Mineral ( $\mathrm{Zn}, \mathrm{Mg}, \mathrm{Ca}, \mathrm{Fe}, \mathrm{Mn}$, and $\mathrm{Na}$ ) contents were determined by atomic absorption spectrophotometry. The triple acid digestion method of Sahrawat et al. (8) was employed. $2.0 \mathrm{~g}$ of sample was mixed with $24 \mathrm{~cm}^{3}$ of concentrated nitric acid $\left(\mathrm{HNO}_{3}\right)$, sulfuric acid $\left(\mathrm{H}_{2} \mathrm{SO}_{4}\right)$, and $60 \%$ perchloric acid $\left(\mathrm{HClO}_{4}\right)(9: 2: 1 \mathrm{v} / \mathrm{v})$, digested for 10 minutes to a clear solution, cooled and transferred into a $50 \mathrm{~cm}^{3}$ volumetric flask and made up to the mark with deionized water. The digests were analyzed for minerals using atomic absorption spectroscopy.

\section{Quantitative Determination of Anti nutrients and Phytochemicals}

Determination of Tannins: $5 \mathrm{~g}$ of each sample was mixed with $100 \mathrm{~mL}$ of $2 \mathrm{M} \mathrm{HCl}$ in a conical flask and boiled for 30 minutes in a water bath. The hot mixture was then cooled, filtered and the filtrate was extracted twice with $40 \mathrm{~mL}$ of diethyl ether. The ethereal extract was then heated to dryness and weighed (9).

Determination of Saponins: $5 \mathrm{~g}$ of each sample was weighed and mixed with $100 \mathrm{~mL}$ of $20 \%$ ethanol. The suspension was heated and stirred continuously on a water bath for 4 hours at about $55^{\circ} \mathrm{C}$. The mixture was then filtered and the residue was re-extracted with $100 \mathrm{~mL}$ of $20 \%$ ethanol. The combined extracts were concentrated on a water bath to a volume of 
about $40 \mathrm{~mL}$. The concentrate was washed with diethyl ether and extracted with n-butanol and the n-butanol extract was washed with $5 \%$ aqueous sodium chloride. The residual solution was first heated in a water bath and then dried in the oven to constant weight. The saponin content was then calculated in percentage (10).

$$
\text { Saponin content }=\frac{\text { Weight of dry residue }}{\text { Weight of sample }} \times 100
$$

Determination of Flavonoids: $10 \mathrm{~g}$ of each sample was extracted with $80 \%$ aqueous methanol repeatedly at room temperature. The extract was then filtered and the filtrate was transferred to a beaker and evaporated to dryness over a water bath. The weight of the material and percentage composition was calculated (11).

$$
\text { Flavonoid content }=\frac{\text { Weight of dry residue }}{\text { Weight of sample }} \quad \times 100
$$

Determination of Total Phenolics: $2 \mathrm{~g}$ of each sample was soaked in $\mathrm{n}$-hexane for about 4 hours. The mixture was then filtered and the procedure repeated on the residue. This is performed to remove all the fat in the sample. The defatted sample was then extracted with diethyl ether (DEE). $10 \% \mathrm{NaOH}$ solution and distilled water were then added to the DEE extract in a separating funnel and the aqueous layer separated was acidified to $\mathrm{pH} 4.0$ by adding $10 \% \mathrm{HCl}$ solution. $50 \mathrm{~mL}$ of dichloromethane (DCM) was then used to finally extract the sample. The organic layer was finally collected, dried and weighed (11).

$$
\text { Total phenolics content }=\frac{\text { Weight of dry residue }}{\text { Weight of sample }} X 100
$$

Determination of Alkaloids: $5 \mathrm{~g}$ of sample was soaked in $200 \mathrm{~mL}$ of $20 \%$ acetic acid in ethanol for 4 hours. The mixture was filtered and the filtrate was concentrated on a water bath to about three-quarter of the original volume. Concentrated ammonia solution was added dropwise to the extract to precipitate the alkaloids. The solution was allowed to settle and the precipitate filtered and weighed (12).

$$
\text { Alkaloid content }=\frac{\text { Weight of dry residue }}{\text { Weight of sample }} \times 100
$$


Determination of Phytates: $4.0 \mathrm{~g}$ of each sample was soaked in $100 \mathrm{~mL}$ of $2 \% \mathrm{HCl}$ for 5 hours and then filtered. $25 \mathrm{~mL}$ of the filtrate was measured into a conical flask and $5 \mathrm{~mL}$ of $0.3 \%$ ammonium thiocyanate solution $\left(\mathrm{NH}_{4} \mathrm{SCN}\right)$ was added as an indicator and $53.5 \mathrm{~mL}$ of distilled water was also added to reach $\mathrm{pH}$ of 3.5. The mixture was titrated with ferric chloride solution $\left(\mathrm{FeCl}_{3}\right)$ until a brownish yellow color that persisted for 5 minutes. Phytate content (mg/100 g) was calculated as: (13)

$$
\text { Phytate content }=\frac{T \times 0.195 \times 3.55 \times 100}{94.5}
$$

Where: $\mathrm{T}=$ titer, and $0.195,3.55$, and 94.5 are constants.

Determination of Oxalates: $75 \mathrm{~mL}$ of $3.0 \mathrm{M} \mathrm{H}_{2} \mathrm{SO}_{4}$ was added to $1 \mathrm{~g}$ of each ground sample and stirred intermittently with a magnetic stirrer for about one hour and then filtered. A 25$\mathrm{mL}$ of a sample of the filtrate (extract) was collected and titrated while hot $\left(80^{\circ} \mathrm{C}\right)$ against $0.05 \mathrm{M} \mathrm{KMnO}_{4}$ solution to the point when a faint pink color appeared that was persistent for at least 30 seconds $(14,15)$.

$$
\text { Oxalates content }(\mathrm{mg} / 100 \mathrm{~g})=\frac{\mathrm{T} \times[\mathrm{Vme}][\mathrm{DF}] \times 2.4 \times 10^{2}}{\mathrm{MEX} \mathrm{Mf}}
$$

Where: $\mathrm{T}=$ titer of $\mathrm{KMnO}_{4}, \mathrm{~V}_{\mathrm{me}}=$ Volume-mass equivalent (i.e $1 \mathrm{~mL}$ of $0.05 \mathrm{M} \mathrm{KMnO}_{4}$ solution is equivalent to $0.00225 \mathrm{~g}$ anhydrous oxalic acid), DF = Dilution factor, VT/A $\mathrm{VT}=$ Total volume of filtrate $(75 \mathrm{~mL}), \mathrm{A}=$ Aliquot used $(25 \mathrm{~mL}), \mathrm{ME}=$ molar equivalent of $\mathrm{KMnO}_{4}, \mathrm{Mf}_{\mathrm{f}}=$ Weight of sample use.

Cyanide content Determination: $4.0 \mathrm{~g}$ of each sample was soaked in a mixture containing $40 \mathrm{~mL}$ of distilled water and $2 \mathrm{~mL}$ of orthophosphoric acid and left overnight at room temperature. This is to release all the bound hydrocyanic acid. The extract was then carefully distilled (using a drop of paraffin as antifoaming agent and broken chips as anti bump). $5 \mathrm{~mL}$ of distillate was collected into a receiving flask containing $40 \mathrm{~mL}$ of distilled water and $0.1 \mathrm{~g}$ of $\mathrm{NaOH}$ pellets and this was transferred to a $50 \mathrm{~mL}$ volumetric flask and made up to mark with distilled water. $20 \mathrm{~mL}$ of this solution was transferred into a conical flask, $1.0 \mathrm{~mL}$ of $5 \%$ potassium iodide solution was added and the solution was titrated against $0.01 \mathrm{M}$ silver nitrate solution. A blank was also titrated until the end point indicates a faint but permanent turbidity (16). 
Oluwaniyi and Oladino, JOTCSA. 2017; 4(3): 661-674.

Data Processing: All data were subjected to the analysis of variance to the significant difference at the 0.05 level (17). SPSS 16.5 was used for the analysis.

\section{RESULTS AND DISCUSSION}

Table 1: Result of proximate analysis.

\begin{tabular}{|c|c|c|c|c|}
\hline Parameters $(\mathrm{g} / 100 \mathrm{~g})$ & 6months TME 9 & 12months TME 9 & 6months TME 7 & 12months TME 7 \\
\hline Moisture & $34.8 \pm 0.62^{a}$ & $44.3 \pm 0.24^{c}$ & $37.5 \pm 0.71^{b}$ & $44.7 \pm 0.47^{c}$ \\
\hline Ash & $2.99 \pm 0.14^{b c}$ & $3.33 \pm 0.21^{c}$ & $2.62 \pm 0.16^{b}$ & $1.33 \pm 0.24^{a}$ \\
\hline Fat & $2.13 \pm 0.20^{a b}$ & $1.38 \pm 0.63^{a}$ & $2.45 \pm 0.15^{b}$ & $1.45 \pm 0.32^{a}$ \\
\hline Crude fibre & $3.21 \pm 0.09^{a}$ & $4.17 \pm 0.6^{b}$ & $3.69 \pm 0.18^{c}$ & $4.56 \pm 0.05^{d}$ \\
\hline Protein & $3.83 \pm 0.05^{a}$ & $2.85 \pm 0.06^{b}$ & $3.31 \pm 0.11^{c}$ & $2.28 \pm 0.21^{d}$ \\
\hline $\mathrm{CHO}$ & $87.83 \pm 0.23^{a}$ & $88.85 \pm 0.44^{a}$ & $87.94 \pm 0.36^{a}$ & $90.38 \pm 0.7^{b}$ \\
\hline *Total Energy & 385.81 & 379.22 & 387.05 & 383.69 \\
\hline
\end{tabular}

$*=$ Total energy in $(\mathrm{Kcal} / \mathrm{g})$. Values are means \pm standard deviations of triplicate determinations. $a, b, .$. Values in the same row sharing the same letters are not significantly different $(p<0.05$ level).

The proximate compositions of the two varieties TME 9 (olekan-aga) and TME 7 (okoiyawo) of Manihot esculenta tubers at different ages (6 months and 12 months) are presented in Figure 1 $(a-f)$. The results show that the moisture content of the samples increase with age i.e. samples harvested after 12 months have more moisture than those harvested at 6 months. For the 6-month samples, the TME 7 variety has higher moisture content than the TME 9 variety. The moisture content of both varieties at 12 months $(44.3 \pm 0.24$ and $44.7 \pm 0.47)$ are similar to those reported by Onabanjo et al. (18) $(41.7 \pm 0.14)$. The ash content of the two varieties at 6 months are similar, but while the ash content increased for TME 9 variety, it decreased for the TME 7 variety. The crude fat contents of 6-month samples are also significantly higher than those for the 12-month samples in both varieties. This means that 6-months TME 9 and 6 -months TME 7 are richer in fat than the 12-month samples. The crude fiber contents of all the samples are significantly different from each other, although for the two varieties, 6-months have the lower fiber content while the 12-months have the higher fiber content with the TME 7 variety having the higher fiber of the two varieties. 

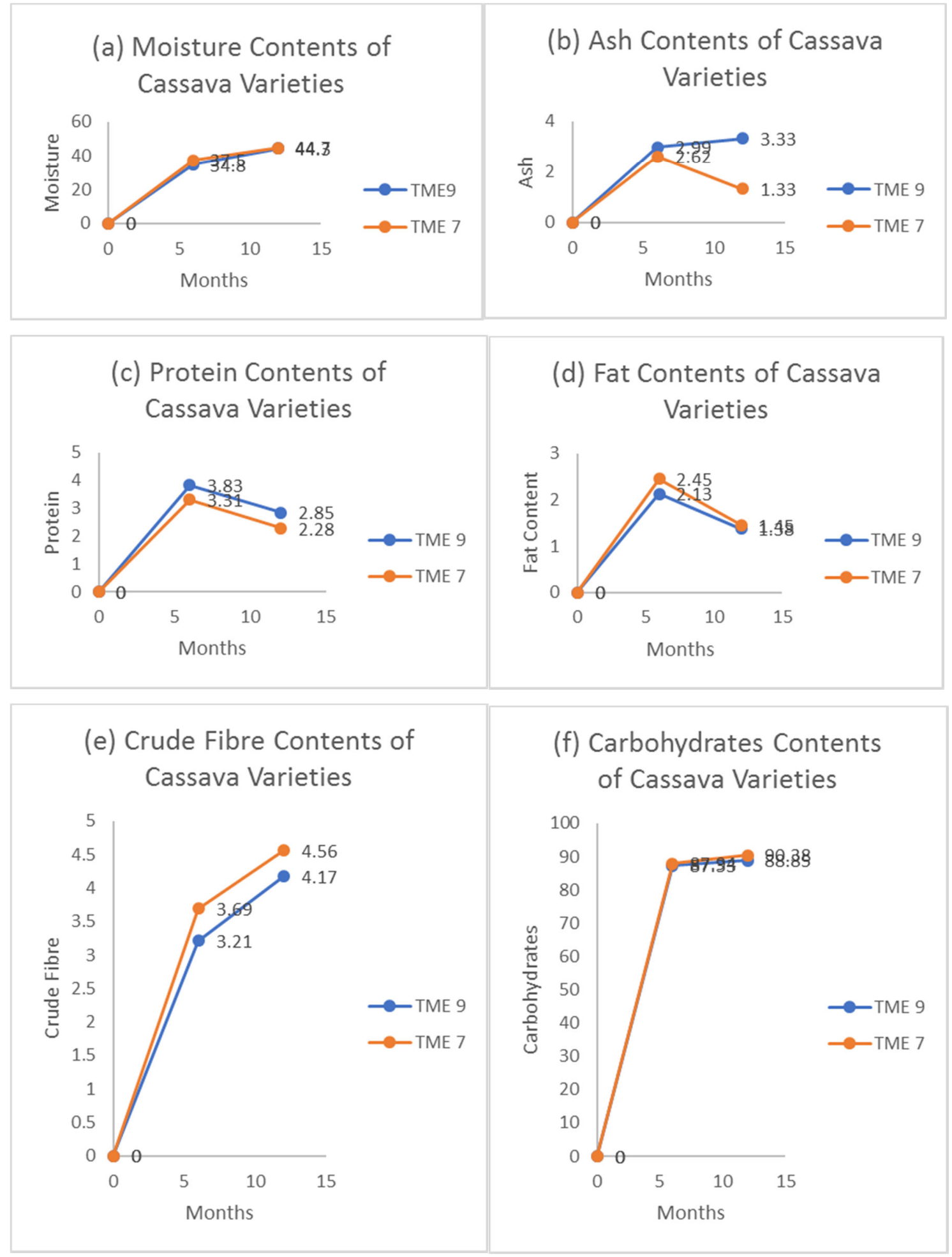

Figure 1: Proximate Composition of Cassava Varieties. 
The fiber content of cassava tubers depends on the variety and age of the tuber (19). The crude protein content in TME 9 and TME 7 varieties of Manihot esculenta tubers are significantly different in both the varieties and ages, but generally the protein contents are higher in the younger (6-months) samples and reduce as the samples mature. Although the carbohydrate contents of all samples are almost all similar, the carbohydrate content of a 12-month sample of TME 7 variety is significantly higher than those of the other samples and the older samples generally have higher starch contents than the 'younger' samples. Since cassava is known to be a major carbohydrate source in diets, it may therefore be advisable to allow the samples mature/grow older before harvesting. Sarkiyayi et al. (20) reported the total carbohydrate as 85.46 and $86.21 \%$ in sweet and bitter cassava respectively. The result is similar to the result obtained in this research. The results also showed that 6 months TME 7 variety is higher in energy level compared to other samples.

Table 2: Mineral composition $(\mathrm{mg} / \mathrm{kg}$ ) of 6-month- and 12-month-old samples of TME 9 and TME 7 varieties of Manihot esculenta tubers.

\begin{tabular}{lllll}
\hline $\begin{array}{l}\text { Mineral } \\
(\mathbf{m g} / \mathbf{k g})\end{array}$ & $\mathbf{6} \begin{array}{c}\text { months } \\
\text { TME 9 }\end{array}$ & $\begin{array}{l}\mathbf{1 2} \text { months } \\
\text { TME 9 }\end{array}$ & $\begin{array}{l}\mathbf{6} \text { months } \\
\text { TME 7 }\end{array}$ & $\begin{array}{l}\mathbf{1 2} \text { months } \\
\text { TME 7 }\end{array}$ \\
\hline $\mathrm{Zn}$ & 52.5 & 151 & 14.5 & 16.25 \\
$\mathrm{Mg}$ & 328 & 324 & 324.8 & 317.3 \\
$\mathrm{Ca}$ & $1,209.5$ & $1,273.3$ & $1,276.8$ & $1,178.5$ \\
$\mathrm{Fe}$ & 322.8 & 319.3 & 532.0 & 250.5 \\
$\mathrm{Mn}$ & 29 & 5.9 & 15.5 & 20.8 \\
$\mathrm{Na}$ & 542.5 & 812.3 & 708.8 & $1,053.5$ \\
\hline
\end{tabular}

The most abundant mineral in the cassava samples is $\mathrm{Ca}$, with the values ranging from $1,178.5-1,276.8 \mathrm{mg} / \mathrm{kg} . \mathrm{Mn}$ is the least abundant of the minerals investigated with values $5.9-29 \mathrm{mg} / \mathrm{kg}$. This result shows that, in addition to cassava being a good source of carbohydrates and especially starch, it is also a good source of other nutrients in reasonable amounts. 
Oluwaniyi and Oladino, JOTCSA. 2017; 4(3): 661-674.

Table 3: Results of quantitative phytochemical composition $(\mathrm{mg} / 100 \mathrm{~g})$ of TME 9 and TME 7 varieties of Manihot esculenta tubers at 6 months and 12 months.

\begin{tabular}{lcccc}
\hline Parameters & 6 months TME 9 & 12 months TME 9 & 6 months TME 7 & 12 months TME 7 \\
\hline Alkaloids & $11.69 \pm 0.43^{a}$ & $16.03 \pm 1.70^{b}$ & $12.49 \pm 0.53^{a}$ & $21.44 \pm 0.56^{c}$ \\
Flavonoids & $3.50 \pm 0.57^{b}$ & $2.10 \pm 0.64^{a}$ & $3.73 \pm 0.19^{b}$ & $2.07 \pm 0.34^{a}$ \\
Saponins & $2.39 \pm 0.23^{a}$ & $4.41 \pm 0.31^{b}$ & $1.84 \pm 0.12^{a}$ & $3.54 \pm 0.25^{c}$ \\
Tannin & $0.22 \pm 0.05^{b}$ & $0.14 \pm 0.03^{a}$ & $0.21 \pm 0.02^{b}$ & $0.13 \pm 0.04^{a}$ \\
\hline
\end{tabular}

Values are means \pm standard deviations of triplicate determinations. $a, b, .$. Values in the same column sharing different letters are significantly different $(p<0.05$ level)

From the results, it was observed that the alkaloid contents of the 12-month samples were significantly higher than those of the 6-month samples for the two varieties, meaning that alkaloid contents increase with age. Alkaloids exist in large proportions in the seeds and roots of plants and often in combination with organic acids (21). They have pharmacological applications as anesthetics and CNS stimulants. Several thousands of alkaloids are known to exist in different plant species but only a few of these have been investigated and exploited for medicinal purposes (21).

On the other hand, flavonoids occurred in higher quantities in the 6-month-old samples of the two varieties, showing that flavonoid contents were decreasing with age. Flavonoids function to protect against allergies, inflammation, free radicals, platelet aggregation, microbes, ulcers, hepatotoxins, viruses, and tumors (22). Plant saponins have antiviral, antimicrobial and anti-fungal activities, boost the effectiveness of some vaccines and knock out some kinds of tumor cells particularly lung and blood cancers (23). The tannin contents of the 12-monthold samples are lower in both varieties than the 6-month-old samples. In Ayurveda, formulations based on tannin-rich plants have been used for the treatment of diseases like leucorrhoea, rhinorrhea and diarrhea (24). 
Table 4: Anti nutrients composition $(\mathrm{mg} / 100 \mathrm{~g})$ of TME 9 and TME 7 varieties of Manihot esculenta tubers.

\begin{tabular}{llll}
\hline Parameters & Oxalates & $\begin{array}{l}\text { Cyanogenic } \\
\text { glycosides }\end{array}$ & Phytates \\
\hline 6 months TME 9 & $31.60 \pm 2.89$ & $16.80 \pm 0.61$ & $0.36 \pm 0.03$ \\
12 months TME 9 & $48.05 \pm 3.09$ & $30.43 \pm 1.24$ & $0.69 \pm 0.01$ \\
6 months TME 7 & $32.09 \pm 4.81$ & $18.77 \pm 0.80$ & $0.48 \pm 0.03$ \\
12 months TME 7 & $38.57 \pm 2.07$ & $32.53 \pm 2.56$ & $0.65 \pm 0.04$ \\
\end{tabular}

Generally, the antinutrients composition of the cassava samples increases with age. The oxalate contents in 12-month-old samples of the two varieties are higher than those of 6-month-old samples. Oxalic acid is toxic to the kidney and heart. Symptoms of mild oxalate poisoning include abdominal pains and gastroenteritis. In severe cases, it can cause diarrhea, vomiting, convulsions, non-coagulability of blood, coma and renal disease (25). The lowest cyanogenic glycoside content was obtained in 6-month-old samples of both varieties. High residual cyanide from poor processing and preparation is known to cause acute cyanide intoxication, and goiters, and has been linked to ataxia (a neurological disorder affecting the ability to walk, also known as konzo). It has also been linked to tropical calcific pancreatitis in humans, leading to chronic pancreatitis (26). The cyanogenic glycoside contents of both varieties must therefore be sufficiently reduced before consumption in order to avoid all side effects. The phytate contents of 12 -month old samples are higher in both varieties than 6-month old samples. Phytic acid has 12 replaceable hydrogen atoms with which it could form insoluble salts with metals such as calcium, iron, zinc, and magnesium. The formation of these salts renders the metals unavailable for absorption into the body (27).

\section{CONCLUSION}

The results obtained from the analysis carried out on the two varieties of cassava TME 9 (olekan-aga) and TME 7 (oko-iyawo) at different ages (6 and 12 months) have clearly shown that cassava tubers contain nutrients, phytochemicals, and antinutrients. For nutrients, most values especially the carbohydrate content increase as plant age increase while the fat and protein content decrease as plant age increase. The analysis also revealed that total energy 
value decrease with plant age. The variation in mineral content does not follow any particular order. The phytochemicals, such as alkaloids and saponins, increase with age while flavonoids and tannin reduce with age. However, all antinutrients concentrations such as cyanogenic glucosides, oxalates and phytates increase with age. The 6 months samples may therefore be more preferred for consumption considering the carbohydrate, energy, phytochemicals, and antinutrient contents. The levels of antinutrients in the cassava samples necessitate adequate processing before consumption and since fortunately, cassava undergoes series of processing before consumption, the level of antinutrients are usually reduced to tolerable levels. Many of the cassava processing operations such as soaking, fermentation, drying, roasting, boiling etc. in addition to making cassava edible and palatable, also work to detoxify cassava.

\section{REFERENCES}

1. Fauquet C, Fargette D. African Cassava Mosaic Virus: Etiology, Epidemiology, and Control. Plant Disease 1990. 74 (6): 404-11. DOI:10.1094/pd-74-0404

2. Gbadegesin MA, Olaiya CO, Beeching JR. Africa cassava: Biotechnology and molecular breeding to the resue. Br Biotechnol J. 2013. 3(3):305-317. DOI:10.9734/BBJ/2013/3449.

3. IFAD/FAO. Proceedings of the validation forum on the global cassava development strategy: A review of cassava in Africa with country case studies on Nigeria, Ghana, the United Republic of Tanzania, Uganda and Benin. 2013. 2:1-66.

ftp://ftp.fao.org/docrep/fao/009/a0154e/A0154E00.pdf

4. Chiwona-Karltun L, Tylleskar T, Mkumbira J, Gebre- Medhin M, Rosling H. Low dietary cyanogen exposure from frequent consumption of potentially toxic cassava in Malawi. Int. J. Food Sci. Nutr. 2002. 51:33-43. http://dx.doi.org/10.1080/096374800100886

5. AOAC, Official methods of analysis (14th Edn.) Arlington, VA: Association of Official Analytical Chemists. 1984

6. Oluwaniyi OO, Dosumu OO, Awolola GV. Effect of cooking method on the proximate, Amino acid, and Fatty acid Compositions of clarias gariepinus and Oreochromis niloticus. J Turkish Chem Soc Section A: Chemistry (JOTCSA). 2017. 4(1): 115 - 132.

DOI: $10.18596 /$ jotcsa. 53143

7. Osborne, DR, Voogt P, The analysis of nutrients in foods. London. Academic press. 1978. 251 p. ISBN 0125291507

8. Sahrawat KL, Kuaar GR, Rao JK. Evaluation of triacid and dry ashing procedures for detecting potassium, calcium, magnesium, iron, zinc, manganese and copper in plant materials. Communication of Soil Sciences and Plant Analysis, 2002. 33(1): 95 - 102. http://dx.doi.org/10.1081/CSS-120002380

9. Okwu DE, Iroabuchi F. Phytochemical Composition and Biological Activities of Uvaria chamae and Clerodendoron splendens. 2009. 6(2): 553-560. downloads. hindawi.com/journals/jchem/2009/190346.pdf 
10. Obadoni BO, Ochuko PO. Phytochemical Studies and Comparative Efficacy of the Crude Extracts of some Homeostatic Plants in Edo and Delta States of Nigeria. Global J. Pure Appl. Sci. 2001. 8: 203 208. https://www.ajol.info/index.php/gjpas/article/view/16033/0

11. Bohm BA, Koupai-Abyazani MR. Flavonoid and condensed tannins from Leaves of Hawaiian Vaccininum vaticulum and V. calycinum Ericaceae. Pacific Sci. 1994. 48(4): 458-463. http://hdl.handle.net/10125/2298

12. Harborne J B. Phytochemical Methods, A Guide to Modern Techniques of Plant Analysis. Chapman and Hall, London. 1973. PP. 113. ISBN: 978-94-010-8956-2

13. Reddy NR, Sathe SK, Salunkle DK. Phytates in Legumes and Cereals. Adv. Food Res. 1982. 28: 1-92. https://www.ncbi.nlm.nih.gov/pubmed/6299067

14. Day RA Jr, Underwood AL. Quantitative Analysis 6th edition, Apprentice- Hall Publication 199. 685p. ISBN-13: 978-0137471553

15. Kayode RMO, Sani A, Oladoye CO, Annongu AA, Arekemase MO, Obalowu MA, Abdulsalam KO. Physico-chemical and anti-nutritional characterization of the kernels of some mango (Mangifera indica) cultivars grown in Western parts of Nigeria Food Science and Quality Management. 2013. 22: $1-8$. http://www.iiste.org/Journals/index.php/FSQM/article/view/9585/9708

16. AOAC, Official Methods of Analysis, 15th Edition, Association of Official Analytical Chemists, Washington, DC., Arlingto n, Virginia. 1990. ISBN: 0-935584-42-0.

17. Steel RG, Torrie JH, Dickey DA. Principle and Procedures of Statistics: A Biometrical Approach. 3 Sub edition. McGraw-Hill Book Company, New York. 1996. 672 p. ISBN-10: 0070610282.

18. Onabanjo OO, Oguntona CRB, Bussie Maziya-Dixon, Olayiwola IO, Oguntona EB, Dixon AGO. Nutritional evaluation of four optimized cassava-based complementary foods African Journal of food science. 2008. 2 (12): 136 - 143. http://www.academicjournals.org/journal/AJFS/articleabstract/513A58817257

19. Montagnac JA, Davis CR, Tanumihardjo SA. Nutritional Value of Cassava for Use as a Staple Food and Recent Advances for Improvement. Comp. Rev. Food Sci and Safety 2009. 8(3): 181 - 194. DOI: $10.1111 / j .1541-4337.2009 .00077 . x$

20. Sarkiyayi S, Agar TM. Comparative Analysis on the Nutritional and Anti-Nutritional Contents of the Sweet and Bitter Cassava Varieties. Advance Journal of Food Science and Technology 2010. 2(6): 328-334. http://maxwellsci.com/print/ajfst/v2-328-334.pdf

21. Madziga HA, Sanni S, Sandabe UK. Phytochemical and Elemental Analysis of Acalypha wilkesiana Leaf. Journal of American Science. 2010. 6(11): 510-514. http://www.jofamericanscience.org/journals/amsci/am0611/60 3940am0611 $510 \quad$ 514.pdf

22. Okwu DE, Nnamdi FU. Evaluation of the Chemical Composition of Dacryodes edulis and Raphia hookeri Mann and Wendl Exudates used in Herbal Medicine in South Eastern Nigeria. Afr J Trad Complement Altern Med. 2008. 5(2): 194-200. https://www.ncbi.nlm.nih.gov/pmc/articles/PMC2816547/

23. Stray F. The Natural guide to medicinal herbs and plants. Dorset House Publishing Co Inc; 2nd Edition edition. 1991. 223p. ISBN-10: 0880298286

24. Kar, A. Phamaocgnosy and Pharmacobiotechnology $2^{\text {nd }}$ Edition. Anshan Publishers, New Delhi, 2007. 880p. ISBN-10: 1905740735.

25. Akpabio UD, Akpakpan AE, Udo UE, Essien UC. Physicochemical Characterization of exudates from Raffia Palm (Raphia hookeri). Adv. Appl. Sci. $\quad 2012 . \quad$ Res., 3(2): 838-843. 
Oluwaniyi and Oladino, JOTCSA. 2017; 4(3): 661-674.

http://www.imedpub.com/articles/physicochemical-characterization-of-exudates-from-raffiapalmraphia-hookeri.pdf

26. Kangas-Dick A, Khan U, Awoniyi O, Waqar S, Tun NN, Viswanathan K, Wong C. A Case of Chronic Calcific Nonalcoholic Pancreatitis. Case Reports in Gastrointestinal Medicine. 2016 (2016), Article ID 2963681, 3 pages. http://dx.doi.org/10.1155/2016/2963681

27. Adeboye AS, Babajide JM. Effect of processing methods on antinutrients in selected leafy vegetables. Nigerian Food Journal, 2007. 25(2): 77-87.

https://www.ajol.info/index.php/nifoj/article/view/50843 
Oluwaniyi and Oladino, JOTCSA. 2017; 4(3): 661-674. 